Article

\title{
Consumer Readiness to Reduce Meat Consumption for the Purpose of Environmental Sustainability: Insights from Norway
}

\author{
Marthe Hårvik Austgulen ${ }^{1, *}$ (D), Silje Elisabeth Skuland ${ }^{1}$, Alexander Schjøll ${ }^{1}$ and \\ Frode Alfnes 1,2 (D) \\ 1 Consumption Research Norway, Oslo Metropolitan University, P.O. BOX 4, St. Olavs plass, \\ N-0130 Oslo, Norway; silje.e.skuland@oslomet.no (S.E.S.); alexander.schjoll@oslomet.no (A.S.); \\ frode.alfnes@nmbu.no (F.A.) \\ 2 School of Economics and Business, Norwegian University of Life Sciences, P.O. BOX 5003 NMBU, \\ N-1432 Ås, Norway \\ * Correspondence: marthe-harvik.austgulen@oslomet.no; Tel.: +47-67-23-57-51
}

Received: 14 August 2018; Accepted: 23 August 2018; Published: 28 August 2018

\begin{abstract}
Food production is associated with various environmental impacts and the production of meat is highlighted as a significant source of greenhouse gas emissions. A transition toward plant-based and low-meat diets has thus been emphasised as an important contribution to reducing climate change. By combining results from a consumer survey, focus group interviews and an in-store field experiment, this article investigates whether Norwegian consumers are ready to make food choices based on what is environmentally sustainable. We ask how consumers perceive the environmental impacts of food consumption, whether they are willing and able to change their food consumption in a more climate-friendly direction, and what influences their perceptions and positions. The results show that there is uncertainty among consumers regarding what constitutes climateor environmentally friendly food choices and that few consumers are motivated to change their food consumption patterns for climate- or environmental reasons. Consumers' support to initiatives, such as eating less meat and increasing the prices of meat, are partly determined by the consumers' existing value orientation and their existing consumption practices. Finally, we find that although providing information about the climate benefits of eating less meat has an effect on vegetable purchases, this does not seem to mobilise consumer action any more than the provision of information about the health benefits of eating less meat does. The article concludes that environmental policies aiming to transfer part of the responsibility for reducing greenhouse gas emissions to food consumers is being challenged by the fact that most consumers are still not ready to make food choices based on what is best for the climate or environment.
\end{abstract}

Keywords: climate change; consumers; meat; sustainable consumption; environment; survey; focus group interviews; in-store experiment

\section{Introduction}

Food consumption is recognised as an environmentally important behaviour, because the production, transportation and consumption of food contribute to environmental problems like climate change, land erosion and excess waste. Our aim with this article is to advance the debate on how everyday activities of consumers can be changed in a more sustainable direction and whether allocation of responsibility to consumers through the use of non-intrusive governance tools, such as information provision, represents a good solution to climate change and other environmental problems. 
We draw on data from three sources to investigate whether Norwegian consumers are ready to make food choices based on what is best for the climate or the environment. We ask how consumers perceive the environmental impacts of food consumption, whether they are willing and able to change their food consumption in a more climate- or environmentally friendly direction, and what influences their perceptions and positions.

In this article, we focus on the consumption of meat, as it has been identified as the most environmentally harmful form of food consumption. If Western consumers are to change to a more environmentally sustainable diet, it is important to reduce the consumption of meat [1-13]. The trend, however, points in the opposite direction. The consumption of meat, dairy and eggs is increasing worldwide [14-16], and in Norway there has been an increase in meat consumption during the last decades from approximately $45.7 \mathrm{~kg}$ per capita in 1989 to $70.5 \mathrm{~kg}$ in 2016 [17]. A central question is therefore how a reduction in the consumption of meat can be achieved.

In Norway, the authorities have so far shown little interest in making major agricultural policy changes in order to reduce the production of meat [18]. On the contrary, the strategy is rather to increase national meat production [19]. There is also no consensus among policymakers on what environmentally friendly consumption of meat actually is [20]. A consequence of this lack of consensus is that much of the responsibility is being transferred to consumers [20], and the government perceives its role as being providers and facilitators of information to consumers [21]. This reflects a general trend within the discourse of sustainable consumption, as consumers are often given an important role as well as responsibility for environmental sustainability. The discourse of ascribing environmental responsibility to the individual consumer has become part of mainstream policy-making, and the distribution of (environmental) information and facilitating of consumer empowerment are regarded as important policy tools [22-25]. Consumers are perceived to be part of the solution, and they are expected to be aware of their responsibility and act responsibly through their decision-making at the point of purchase [26-29]. This strategy is part of a regulatory regime based on voluntarism, market solutions and the state acting at a distance [30-34], and it requires significant consumer engagement in order to be successful. Consumers need to be aware of the environmental impact of their food consumption, they need to think that changing their personal diet represents a solution to the problem, and they need to be willing and able to make this change.

According to Pohjolainen et al. [35], relatively little attention has been paid to consumer understanding of the environmental implications of meat eating. Hence, in this article we investigate whether these necessary requirements are in place and whether the strategy of providing information to consumers is perceived as effective.

The article is organised as follows: In the following section, we review the existing literature on factors influencing consumers' willingness to change to a more plant-based diet. Then follows a presentation of the various methods we have used to gather data for our study. Thereafter our empirical findings are presented, synthesised and discussed. Finally, we conclude with a discussion of the implications of our findings for sustainability and consumer policies.

\section{Prior Topical Research: Factors Influencing Environmentally Sustainable Meat Consumption}

Many consumers have been found to be reluctant to eat less meat for climatic and environmental reasons [36-39]. The literature on pro-environmental behaviour related to meat consumption has identified several factors that can help explain why this is the case. In this literature, most studies focus on individual explanatory factors.

A common finding in the literature is that relatively few consumers have developed certain awareness of the environmental impacts of meat consumption. Consumers often underestimate the impacts of meat consumption on climate change compared to other actions such as recycling, favouring local, organic and seasonal foods, and reducing food waste and excessive packaging, and express scepticism of scientific evidence linking meat and climate change [35-52]. This limited knowledge functions as a barrier since knowledge about the negative environmental impact of meat consumption 
is associated with higher willingness to change meat consumption behaviour [53-55]. On the other hand, previous research has also described the paradox of consumer unwillingness to change dietary habits combined with a general perception of personal duties towards preserving the environment, promoting public health and safeguarding animal welfare [56].

Consumers' willingness to reduce meat consumption is influenced by cultural and social values and by related habits and routines [10,57]. Consumers can be hesitant to reduce their meat consumption because they see meat as pleasurable, social and traditional $[35,36,51,58]$, they feel that they lack the familiarity and skills needed to prepare vegetarian meals [12,49,59], and because they are worried about being viewed as "wimpy" or "strange" if they do not eat meat [50]. Furthermore, Schösler et al. [12] found that there are large cultural differences in people's willingness to reduce meat consumption. This may be related to differences in cuisine and meat consumption frequencies as both higher meat consumption frequencies and positive attitudes towards meat are associated with lower willingness to reduce meat consumption $[46,47,53,60]$. One example of such positive attitudes is that some consumers have strong health beliefs around meat, with a core belief that meat is essential and that a reduction would result in a lack of essential nutrients [51]. Consumers perceiving meat consumption as unhealthy have, on the other hand, been found to be more likely to be willing to reduce their consumption of meat $[36,49,60]$.

Values and attitudes towards climate change are also found to be predictors of willingness to reduce meat consumption and choose more sustainable products. In particular, having universalistic values, thinking that everyone should be treated equally and have the same opportunities, is associated with being more likely to favour free-range meat [61], being vegetarian [62], and having a low level of meat consumption [58,61]. Concern for environmental problems is associated with positive appraisals of various less-meat initiatives among Belgian students [54]. Being sceptical about the seriousness of climate change is negatively associated with the perception of the idea of a meat-free meal per week [44], and with support for and willingness to pay for beef grown using climate-friendly production practices [63].

Another influencing factor identified in the literature is consumers' level of self-efficacy. Although consumers in general do not find it easy to change their diets, the individuals most willing to change their meat consumption are those whose self-efficacy and response efficacy vis-à-vis the recommended action is high $[35,63,64]$.

A final internal influencing factor identified in the literature is gender. Compared with men, women are more likely to be willing to reduce their meat consumption and to believe that meat consumption has a considerable environmental impact $[37,53,55,58,65,66]$.

A few studies have also pointed to external and contextual factors influencing sustainable meat consumption. The grocery-shopping environment dominated by supermarkets, and the supermarkets' assortment, is found to be important as it directly influences the consumer's decision set. This shopping environment defines and restricts what consumers choose from as opposed to bigger behavioural shifts towards different types of food [59]. Furthermore, convenience and price motives have been found to function as barriers to substituting meat with plant proteins [67]. Lastly, the lack of transparency in the meat market [68] and consumers' attitudes towards the food production system in general [63] have been found important.

These studies highlight a resistance to eating less meat and point to different causes of this resistance in multiple countries. These studies rely on various methods, including consumer surveys and interviews, but most studies rely on one data source only. We use the explanatory factors identified in previous studies to guide our research, and seek to combine different types of data to get a broader understanding of consumer readiness to reduce meat consumption.

\section{Materials and Methods}

This article presents data retrieved using three different methods. We seek to increase the validity and reliability of our conclusions by approaching the same research question through different 
analytical lenses. The data were collected successively, allowing interesting findings to inform the next mode(s) of data collection. We started with a representative consumer survey where we investigated consumers' knowledge about climate impacts of meat consumption as well as their perceptions of environmental measures related to food and meat consumption. These data make it possible to investigate effects of value variables, knowledge variables, practice variables and socio-demographic variables. Thereafter, four focus groups were held on the topic to further explore consumer attitudes, knowledge, motivations and practices. Finally, we tested the effect of information measures on consumer behaviour through an in-store experiment.

\subsection{Survey}

The survey data were collected through TNS Gallup's Norwegian web panel in November 2011. The panel consisted of 50,000 pre-recruited Norwegian respondents and was certified according to ISO 26362. The panel sample was pre-stratified by age, gender and residence, and the respondents were randomly selected within these groups [69]. The survey was sent to 3500 respondents, and it was viewed by a total of 1739 respondents. Among these, 92 did not return complete answers, and 115 opened the survey but did not fill it out. The 1532 respondents who completed the survey thus constitute $44 \%$ of to the total, and $88 \%$ of all those who opened the survey. The questions were not forced and many of them had nonresponse options such as "don't know", leading to a lower number of respondents than 1532 in several of the analyses presented in the results section. The sample in this study consist of 1532 respondents who are 18 years and older. Overall, the sample is in line with the population distribution in Norway, with some exceptions regarding age and education. The age group 30-39 is weakly under-represented, while respondents aged 60 years and older is weakly over-represented. The education level in our sample is slightly lower than the education level of the general population. However, due to different sampling methods and categories used in the official education statistics and our sample, these statistics are not directly comparable. See Appendix A for detailed sample characteristics. In the analysis, we used weights corresponding to the population distribution. The focus of the survey was attitudes to climate change and climate policy, and included several questions on the role of consumers and own consumption practices. A special focus was placed on the environmental effect of production and consumption of meat and on possible ways of regulating such consumption. The data were analysed using SPSS 24. The operationalisation of the variables used in the analysis is presented in Appendix B. The full dataset for the survey is available at the Norwegian Centre for Research Data.

\subsection{Focus Group Interviews}

Based on the findings from the consumer survey, we conducted four semi-structured focus group interviews in April 2013 in order to examine how consumers reflect upon the environmental impacts of their food consumption and their willingness to change their food consumption in a more climate-friendly direction. The focus group interviews were structured around three separate themes. The first included semi-structured questions about everyday food consumption such as eating habits concerning meat and vegetables, food preferences, food procurement and cooking. The second theme included group work, where the participants were asked to comment on meat-free dinner recipes, in-store marketing of climate-friendly food, climate labels, sale campaigns and climate-friendly food choice options on food apps. The third theme included a discussion of willingness to change to less or no meat.

The participants were recruited from the Norstat panel, which consisted of approximately 80,000 pre-recruited individuals between the age of 15 and 79 years [70]. All participants reported that they eat meats and vegetables in accordance with a typical Norwegian consumption pattern. The 24 participants were placed in four focus groups categorized by age, gender and marital status (single women 25-35, single men 25-35, married women 36-45 and married men 36-45). See Table A4 
in Appendix $C$ for detailed information about the participants. The participants received a gift voucher of NOK 500 for taking part in the focus group interviews.

All four focus group interviews lasted two hours and were recorded digitally, transcribed and analysed by systematically coding opinions and reflection in a two-step process using the qualitative software program HyperResearch. First, we analysed the transcripts by extracting empirical codes from the discussion among the participants. Secondly, we developed thematic categories from the initial empirical analysis [71]. Focus group interviews produce discursive data. Thus, a concern is that discussions between the participants may silence some opinions or experiences [72-74]. Dividing the participants into two smaller groups allowed participants to talk more freely in the last part of the discussion, wherein we addressed possible effects of in-store promotion of vegetables dinners, such as price reduction, food labelling, information campaigns and vegetable recipe booklets.

\subsection{In-Store Experiment}

In order to study the behavioural effect of providing information about climate-friendly food, we conducted an in-store experiment in four large grocery stores in the Oslo area during two weeks of March 2014. After initial discussions with the chain management about research design and needs, the chain management selected the four stores they considered best suited for our study. The stores were considered well managed and had stable sales. To mitigate noise from changes in customer base or competition, all four stores were in established neighbourhoods. Furthermore, neither of the stores had made changes to the store concept or floor plan in the last year.

We set up stands with recipe booklets promoting vegetable dishes, and collected data on the number of booklets taken. The choice of recipe booklets as the main treatment was based on the discussions in the focus groups, as the focus group participants were positive about vegetarian recipe booklets as a measure that could reduce meat consumption. To keep the appearance of our materials similar to other promotional materials used in the stores, the retailer's design agency created the stands and booklets.

We created two versions of the booklet and booklet stands, one focusing on health benefits and one focusing on climate benefits. The stand and booklet with the health framing was designed to represent a typical vegetable promotion in Norwegian stores. The stand and the booklets had the title "Vegetable dinner-good for your health!", and the logo of the "Information office for fruit and vegetables". The stand and the booklets with the climate framing had the title "Vegetable dinner-good for the climate!", and the logo of the environmental organisation "Future in our hands". The content of the booklets was identical except for the framing on the front page and a short text on the health and climate benefits of eating vegetables on the second page. Both booklets were 20 pages and had the same vegetable dinner recipes. See Figures A1 and A2 in Appendix D for illustrations. To our knowledge, this was the first promotion of vegetables as a climate-friendly food in Norwegian stores.

Two of the four stores started with the health booklets, while the other two started with the climate booklets. After one week, we changed the booklet types so all four stores tested both treatments. We placed the booklet stands so that they were visible to all customers entering the stores as they walked by the fruit and vegetable section. See Appendix D for pictures showing the stands and the recipe booklets, and their placement in the fruit and vegetable section. Results were analysed using Stata.

In addition to the information about the number of booklets taken, the chain management agreed to give us information about the number of kilograms of fruits and vegetables sold at each of the four stores during the experiment. As a control, we received sales data from the corresponding dates the year before. Using the aggregated numbers for each store, we mitigated noise from product-specific price or quality changes. See Appendixs $\mathrm{E}$ and $\mathrm{F}$ for more detailed sales data. 


\section{Results}

\subsection{Perceptions of the Environmental Impacts of Meat Consumption}

The participants were asked to rank four activities according to environmentally friendliness from 1 to 4 , where 1 is the most environmentally friendly using the following question: "Production, distribution and consumption of food is connected with significant environmental impact. Which of the following measures do you think will have the greatest impact on the environment?" Figure 1 illustrates the respondents' rankings of the four alternatives. Responding to the question, the consumers tended to underestimate the environmental impact of meat consumption. According to Hoolohan et al. [7], eliminating packaging, air-freighted food and food waste from the food system would reduce greenhouse gas emissions by $12 \%, 5 \%$ and $3 \%$, respectively, compared with $35 \%$ reduction by eliminating meat from the diet. Our survey showed that Norwegian consumers rank purchasing organic food (mean $=3.10$ ) and foregoing meat (mean $=2.90)$ as the least environmentally beneficial alternatives. Increasing the production of locally produced food (mean $=2.03$ ) and reducing food waste (mean $=1.97$ ) are ranked as the most environmentally beneficial measures. Furthermore, almost a third of the respondents answered that they did not know or that neither of the alternatives were environmentally beneficial. Respondents who claimed that they do not know, that neither of the alternatives is environmentally beneficial, and those who have not completed the ranking were excluded. This shows that the reduction of meat consumption is perceived as an inefficient alternative.

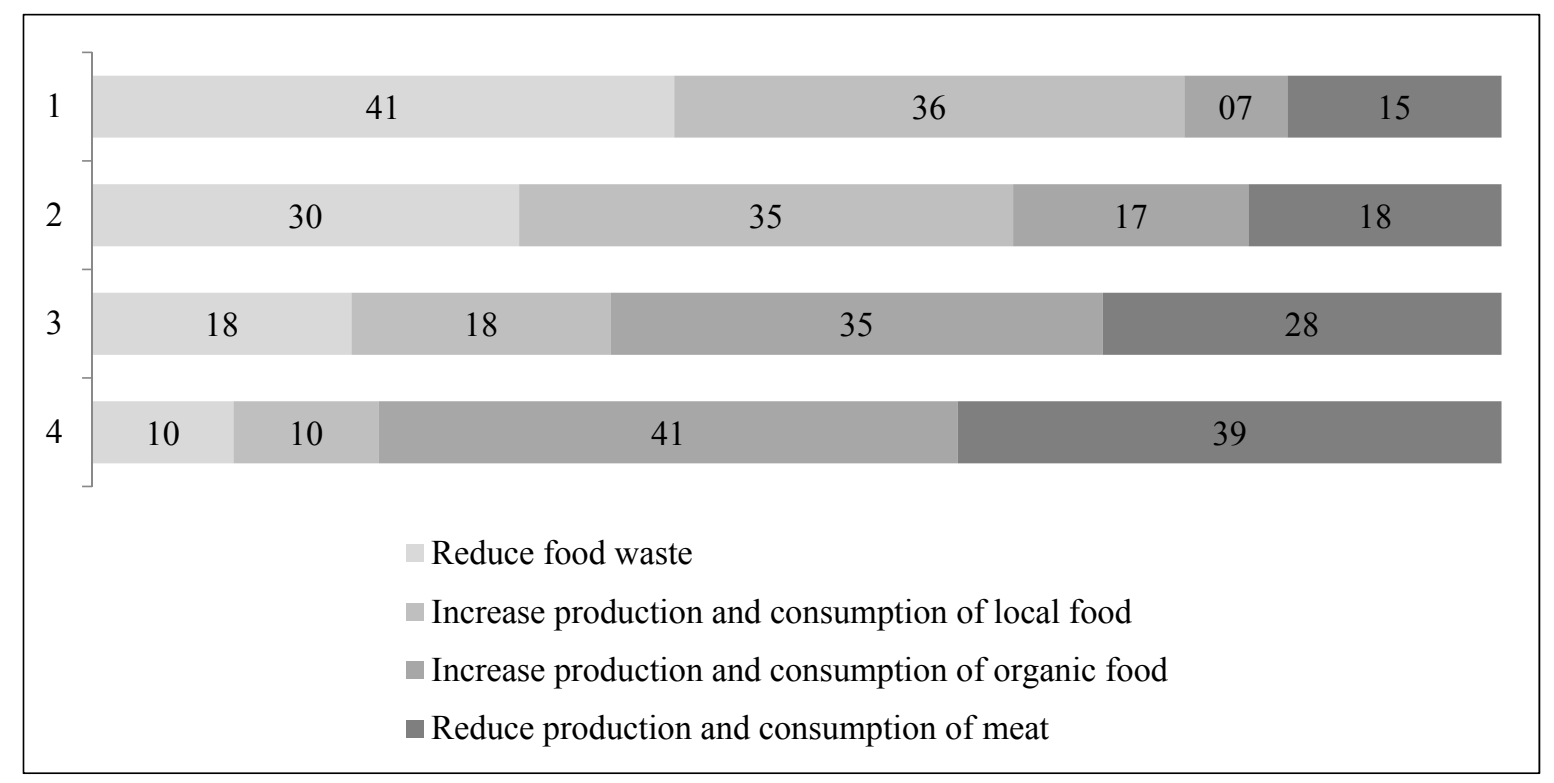

Figure 1. Respondents' ranking of the perceived environmental benefit of four measures. Percent shown for the rankings of each measure, where 1 is the most environmentally friendly $(N=1049)$. 


\subsection{Attitudes to Environmental Measures and Influencing Factors}

We also asked the respondents to state their opinion about two statements on potential environmental measures, presented in Table 1.

Table 1. Support for potential environmental measures. Shown in percent $(N=1530)$.

\begin{tabular}{|c|c|c|c|c|c|c|c|}
\hline & Strongly Disagree (1) & Disagree (2) & Neutral (3) & Agree (4) & Strongly Agree (5) & Mean & Do not know \\
\hline $\begin{array}{l}\text { It is a good idea for the } \\
\text { environment to have a } \\
\text { meat-free day per week }\end{array}$ & 15 & 9 & 18 & 23 & 26 & 3.40 & 9 \\
\hline $\begin{array}{l}\text { The prices on meat products } \\
\text { should be increased for } \\
\text { environmental reasons }\end{array}$ & 38 & 23 & 19 & 11 & 5 & 2.20 & 4 \\
\hline
\end{tabular}

The first statement concerns the idea of having one meat-free day per week. The way the statement is phrased, it measures attitudes to the environmental effect of reducing meat consumption/having a meat-free day per week more than it measures support to this as an actual measure, but it gives an indication of the potential support such a measure could get. Almost $50 \%$ of the respondents agree, and $24 \%$ disagree, that it is a good idea for the environment to have a meat-free day per week. In comparison, only $14 \%$ of the respondents claim to actually have reduced their consumption of meat due to environmental reasons and $34 \%$ of the respondents find it hard to reduce their own meat consumption (not shown). As shown in Table 1, few respondents are positive towards manipulating meat prices for environmental reasons. A majority, more than $60 \%$ of the respondents, disagree with the statement claiming that the prices on meat products should be increased for environmental reasons, while only $16 \%$ agree.

Table 2 displays the results of two independent hierarchical OLS regression analyses with the support for a meat-free meal per week and the support for increased prices on meat products as dependent variables. The reference categories in the analyses are given in parentheses and the operationalisations are presented in Appendix B. Previous studies suggest that both socio-demographic variables and value variables are important determinants of pro-environmental behaviour, and regression analyses show that these factors are also influential in our sample. When the demographic variables are introduced separately, gender, age and education are found to be significant predictors of support for meat-free meals, and gender, education and income are found to be significant predictors of support for increased prices on meat for environmental reasons. However, the socio-demographic variables lose significance when value variables are introduced in the model, and none of the socio-demographic variables are still significant when the practice variables are introduced. The models with only the socio-demographic variables have a relatively low explained variance. This indicates that variations in the socio-demographic variables have a limited effect on the respondents' support for both measures, and that values and reported practices act as partly mediating variables for gender, age, education and income. 
Table 2. Regression analyses on determinants of support for potential meat reduction measures.

\begin{tabular}{|c|c|c|c|c|c|c|c|c|}
\hline & \multicolumn{4}{|c|}{ Meat-Free Meal } & \multicolumn{4}{|c|}{ Increase Prices } \\
\hline & Para & SE & $R^{2}{ }_{\text {adj }}$ & $\Delta R_{\text {adj }}^{2}$ & Para & SE & $R_{\text {adj }}^{2}$ & $\Delta R_{\text {adj }}^{2}$ \\
\hline Step 1 & & & 0.03 & 0.03 & & & 0.04 & 0.04 \\
\hline Constant & $3.1 * *$ & 0.11 & & & $2.17^{* *}$ & 0.10 & & \\
\hline Female & $0.32 * *$ & 0.09 & & & $0.30^{* *}$ & 0.08 & & \\
\hline Age (low) & $0.06^{*}$ & 0.03 & & & -0.01 & 0.02 & & \\
\hline Education (low) & $0.40^{* *}$ & 0.10 & & & $0.43^{* *}$ & 0.08 & & \\
\hline Income (low) & -0.06 & 0.04 & & & -0.08 * & 0.03 & & \\
\hline Income residual category & -0.06 & 0.18 & & & -0.14 & 0.16 & & \\
\hline Step 2 & & & 0.20 & 0.17 & & & 0.22 & 0.18 \\
\hline Constant & $4.25^{* *}$ & 0.16 & & & $3.40^{* *}$ & 0.14 & & \\
\hline Female & $0.19 *$ & 0.08 & & & $0.19 * *$ & 0.07 & & \\
\hline Age (low) & $0.07^{* *}$ & 0.03 & & & 0.00 & 0.02 & & \\
\hline Education (low) & 0.05 & 0.09 & & & 0.13 & 0.08 & & \\
\hline Income (low) & -0.00 & 0.03 & & & -0.03 & 0.03 & & \\
\hline Income residual category & 0.22 & 0.17 & & & 0.12 & 0.14 & & \\
\hline $\begin{array}{l}\text { Individualistic values (collectivistic } \\
\text { to individualistic values) }\end{array}$ & -0.21 * & 0.06 & & & $-0.31^{* *}$ & 0.05 & & \\
\hline $\begin{array}{l}\text { Climate scepticism } \\
\text { (trust to scepticism) }\end{array}$ & $-0.6^{* *}$ & 0.05 & & & $-0.47^{* *}$ & 0.04 & & \\
\hline Step 3 & & & 0.28 & 0.08 & & & 0.29 & 0.07 \\
\hline Constant & $4.53^{* *}$ & 0.17 & & & $3.54^{* *}$ & 0.15 & & \\
\hline Female & 0.04 & 0.08 & & & 0.06 & 0.07 & & \\
\hline Age (low) & 0.03 & 0.03 & & & -0.04 & 0.02 & & \\
\hline Education (low) & 0.02 & 0.09 & & & 0.11 & 0.07 & & \\
\hline Income (low) & 0.00 & 0.03 & & & -0.02 & 0.03 & & \\
\hline Income residual category & 0.14 & 0.16 & & & 0.07 & 0.14 & & \\
\hline $\begin{array}{l}\text { Individualistic values (collectivistic } \\
\text { to individualistic values) }\end{array}$ & $-0.19^{* *}$ & 0.05 & & & $-0.29^{* *}$ & 0.05 & & \\
\hline $\begin{array}{l}\text { Climate scepticism (trust in climate } \\
\text { science to scepticism) }\end{array}$ & $-0.47^{* *}$ & 0.05 & & & $-0.36^{* *}$ & 0.04 & & \\
\hline Hard to reduce meat consumption & $-0.23 * *$ & 0.03 & & & $-0.16^{* *}$ & 0.03 & & \\
\hline Have reduced meat consumption & $0.63^{* *}$ & 0.11 & & & $0.63^{* *}$ & 0.09 & & \\
\hline $\begin{array}{l}\text { Have reduced meat consumption } \\
\text { residual category }\end{array}$ & 0.46 & 0.15 & & & $0.63 *$ & $0.09^{* *}$ & & \\
\hline $\mathrm{N}$ & 1112 & & & & 1162 & & & \\
\hline
\end{tabular}

Notes: ${ }^{* *},{ }^{*}$ indicate significance at $1 \%$ and $5 \%$, respectively. Reference categories in parentheses. See Appendix B for operationalisation of variables.

When the value variables measuring individualistic values and climate scepticism are introduced in estimation Step 2, the explained variance (adjusted $R^{2}$ ) increases from 0.03 to 0.20 for the meat-free-meal model and from 0.04 to 0.22 for the increased-prices model. Both the idea of a meat-free meal per week and increased prices for meat products are received more negatively by respondents who are more sceptical towards climate change, and who are holders of individualistic values, all else being equal. This result indicates that values and climate change attitudes are determining factors.

When the variables measuring perceived difficulty of reducing individual meat consumption and whether or not the respondents have already reduced their consumption of meat are introduced to the model, the explained variance increases even further to 0.28 and 0.29 , respectively. Together, the variables thus explain almost $30 \%$ of the variance in both regression models. Not surprisingly, respondents who say that it is hard to reduce their consumption of meat are more critical both towards the idea about a meat-free meal per weak and increased prices of meat for environmental reasons. Correspondingly, respondents who claim to have already reduced their level of meat consumption for environmental reasons are more positive towards both strategies. 


\subsection{Reasons for Consumers to Not Make Changes to Their Diets}

The focus group interviews provide similar results to the survey. Most participants had limited knowledge about the environmental impact of their food consumption. Instead, participants reported that they were preoccupied with healthy eating, cooking from scratch, avoiding eating too much ready-made or processed food, and preparing and eating tasty meals.

Moreover, while the participants varied in terms of eating habits around meat and vegetables, discussions among the participants illustrated the importance of eating proper dinners. Male participants typically argued that a proper meal included meat. David (33) provided a typical answer to the question of what kind of food ingredients would make up a dinner: "A proper dinner really needs meat, vegetables and sauce." Fred (37) described his preferred dinner plate as: "Large portion of meat, then potatoes, and then a small portion of vegetables." In comparison, some of the female participants said that meat was not necessary in order to eat a proper dinner or become full. For example, Carol (31) said: "For me it might just be salad." The male participants were in particular worried that a meal without meat would be less filling, and some argued that reducing meat consumption would reduce their life quality, while emphasising the importance of meat in everyday dinners.

Many claimed to have reduced their meat consumption as part of healthy eating. Charlotte (29) said, "I don't eat a lot of red meat anymore. I kind of get these heart [disease] associations." Some of the participants said that they have replaced red meat with chicken.

None of the participants said they would like to become a vegetarian or make large cutbacks in their meat consumption. Of all 24 participants, only two said that they tried to avoid eating meat for ethical reasons. Christine (25) said that she avoids chicken because she had "heard rumours that the chicken is not treated that well". This statement reveals that ethical concerns may indeed nudge consumers into changing their diets, but as Charlotte (29) said, after a week she would usually have forgotten all about it. In fact, most participants said that they are tired of all kinds of instructions "telling us what is incredibly unhealthy all the time or dangerous for us" (Elaine, 42), and that such information becomes "piled up and stored away, really" (Dylan, 33). When asked to consider several in-store measures, the participants favoured measures such as price reduction, recipe booklets and vegetable dinner apps for smartphones. However, when the campaigns they were asked to consider mentioned the words "climate-friendly" or "reducing climate impact", most participants got rather critical. In fact, some said that they would prefer that the measures were taken in silence. "If it is beneficial for the climate, then wrap it in. Don't write it down. Rather let it be a side effect" (Dustin, 32).

Overall, participants were rather reluctant to change their diets in a more sustainable direction, with some arguing that they would need serious proof of the environmental impact of meat consumption to change their diets. Meanwhile, most participants were unaware about the climate impacts of food consumption in general and of the impacts of meat in particular. The majority of participants believed in anthropogenic climate change, but many argued that they do not think consumers can solve such a major issue. The male participants were less approving of consumer responsibility, while the women were more divided-the young women were most positive about changing their consumption. Most of the young women said that they would be receptive to in-store campaigns and information suggesting consumers replace meat with vegetables in their diet. The rest of the women, as well as the men, expressed scepticism about and reluctance to changing their eating habits in a more climate-friendly direction.

The focus group interviews illustrate that, despite having limited knowledge about the climate impacts of meat consumption and expressing scepticism towards campaigns instructing consumers to change their diets, many considered increasing the consumption of vegetables and reducing meat consumption as being important for a healthy diet. Focus group participants mentioned other food-related values such as cooking from scratch and preparing and eating tasty meals, in which meat-eating plays an important role for them. Moreover, participants expressed the need for serious proof in order to be persuaded to change their food habits in order to reduce climate change, or wished that climate-friendly initiatives would be introduced in silence. 


\subsection{Limited Effect of In-Store Promotion of Vegetarian Dinners}

During the in-store experiment, taking place over a two-week period, customers took 446 health booklets and 456 climate booklets from the stands in the four stores. The difference is not statistically significant (proportional test of equal share: $\mathrm{z}=0.37, p=0.64$ ). This indicates that framing the in-store marketing campaign as a climate initiative did not spur any additional interest in recipes for vegetable dinners compared to the health framing.

To investigate the effects of the in-store promotions on the sale of vegetables, we ran a regression using the total daily sales of vegetables in kilograms from the four stores for the treatment period and the corresponding days the year before. We controlled for store and weekday. As seen in Table 3, the results show that both types of in-store promotion had an effect on the total sales of vegetables. The stores sold approximately 10\% more vegetables per day under the treatment period compared to the year before. This is higher than the general increase in vegetable sales in Norway of 1\% from 2013 to 2014 [75]. However, the results also show that the effects on vegetable sales of the two treatments were not significantly different. Although we cannot dismiss that the two treatments might have triggered consumers with different characteristics, we interpret the results as indicating that the increase in sales was a result of the sales promotion itself and that the framings were less important. The increased sale of vegetables is consistent with the literature on sales promotions on food consumption. In a review of the literature, Corinna [76] finds that sales promotions lead to significant short-term sales increases; however, the long-term effects are often less evident.

Table 3. Regression of in-store promotions on sales of vegetables.

\begin{tabular}{ccc}
\hline & \multicolumn{2}{c}{ Vegetable Sales } \\
\hline & Para & SE \\
\hline Constant & $422.52^{* * *}$ & 48.81 \\
Health $^{\mathrm{a}}$ & $46.08^{* * *}$ & 14.58 \\
Climate $^{\mathrm{a}}$ & $46.79^{* * *}$ & 14.58 \\
\hline$N$ & 108 & \\
Adjusted $^{2}$ & 0.80 &
\end{tabular}

Notes: The dependent variable is total sales of vegetables per store per day. $N$ is the number of days times number of stores, $27 \times 4$. Controlling for stores and weekdays in the estimation. ${ }^{* * *}$ indicates significance at $1 \%$. ${ }^{a}$ Dummy variables equal one if treatment, zero otherwise.

\section{Discussion}

\subsection{Information to Tackle Low Consumer Awareness}

Our findings show that Norwegian consumers have limited knowledge about the environmental impacts of meat consumption. A majority think that reducing food waste and increasing the production of locally produced food are more effective environmental measures than reducing meat consumption. Many of the consumers in the focus groups were also unaware of the negative climate impacts of production and consumption of meat. This underestimation of the climate impact of meat among Norwegian consumers is similar to previous findings with consumers from other countries [36,37,40,41,49,51,60]. The low awareness among Norwegian consumers may partly be explained by the way meat production is discussed and framed in the Norwegian public discourse. Meat production constitutes an important part of Norwegian agricultural production, and it is heavily subsidized. In the public debate on the environmental impact of meat consumption, Norwegian agricultural organizations promote Norwegian meat production as environmentally sustainable and argue for increased production of meat in Norway. Furthermore, they tie Norwegian meat production to local production, which is also emphasised as environmentally sustainable [20].

Although the low consumer awareness is not the sole reason for the limited consumer engagement, it stands out as an obvious barrier to environmentally sustainable meat consumption. One solution, often pointed to in research and policy, is to provide more information to consumers. However, several 
studies have found that more information in itself is often insufficient to change consumption patterns (e.g., $[54,58,77])$. Umberger et al. [78] found that information related to beef production processes increased the probability that consumers would pay a premium for grass-fed beef, in particular if the information was health-related. Others have argued that the promotion of the climate benefits of reduced meat consumption should be coupled with the associated health benefits [44], or that the focus should be placed on the health benefits alone as this personal benefit appears to have a greater potential to support behaviour change [49]. Our results show that providing consumers with information about the climate benefits of a vegetable-based diet in recipe booklets distributed in supermarkets had some effect on actual consumption choices. Nevertheless, contrary to what we could expect based on previous findings and recommendations, the effect of this information did not differ from the effect of providing information about the health benefits of the same diet. The results of this study support the notion that being informed about the climate benefits of a vegetable-based diet is necessary, but not sufficient, for a majority of consumers to deliberately act in an environmentally sustainable manner.

\subsection{Challenge of Low Consumer Willingness to Alter Their Diets}

The focus groups point to some of the main reasons why Norwegian consumers hesitate to reduce their meat consumption for environmental reasons. In addition to the low awareness discussed above, the role of meat in what is considered a "proper dinner" is important. Some of the participants say it would be difficult to adapt to a low-meat diet without this conflicting with their life quality. This is confirmed by the survey findings, which show that consumers who find it difficult to reduce meat consumption are more negative than others to the idea of a meat-free meal per week and to increase the prices of meat products for climate reasons. These results are in line with previous findings emphasizing the functions of meat as being pleasurable and as a way to express and follow traditional and social values $[35,36,49,51]$, as well the implications of meat attachment $[46,47,53,60]$. Some focus group respondents also point to the very limited impact changes in their consumption practices would have. According to Wibeck and Linnér [79] (in [24]), such an expression of limited agency and knowledge can be seen as ways of negotiating one's perceived responsibility. These findings indicate that eating habits are strongly routinized and often difficult to change, and that it might be easier for consumers to adapt their attitudes and beliefs to their consumption practices than the other way around. The lack of willingness and/or opportunities to change meat consumption practices may encourage consumers to adopt resistant viewpoints functioning as defence mechanisms [80].

Previous studies have found a positive relationship between high perceived consumer effectiveness and the likelihood of engaging in sustainable behaviour $[35,63,64,81]$. It is thus a possibility that consumers can become more willing to change their diet if they are convinced about the climate benefits of their individual, as well as collective, efforts. According to Vermeir and Verbeke [81], perceived consumer effectiveness can be positively influenced through education, communication and targeted information. Furthermore, the consumer survey results show that consumers with collectivistic values, and consumers who believe that climate change is real, anthropogenic, and that it represents a threat, are more likely than others to support the idea of a meat-free meal per week and of increasing the prices of meat products for climate reasons. This indicates that educating consumers about climate change in general can affect their support for these ideas and that the effect of policies aimed at engaging consumers depends on the values and political affiliation of the individual consumers. The importance of existing values further means that efforts to inform, educate and encourage consumers to change their diets in a climate-friendly direction would be most effective before strong value identities are formed, for instance as part of primary education [82].

\subsection{Policies Seeing Consumers as Change Agents}

Overall, focus group respondents were critical of placing too much responsibility on consumers. Some had difficulties seeing that changes at the individual consumer level could result in any real climate impact, arguing that the climate problem had to be resolved at a higher level and that reducing 
meat consumption was not necessarily the most important measure. This perception, that other human activities are more important and should be targeted first, is supported by previous studies $[36,83]$. Other focus group participants stressed the difficulties of taking responsibilities they felt were allocated to them as consumers. They were tired of campaigns that encouraged them to change their diets for one reason or the other. This consumer fatigue points to one of the major challenges of placing much responsibility on individual consumers, namely that consumers have a limited attention span, which makes it difficult, if not impossible, to consider all aspects and potential effects of their consumption at all times. This has been termed Consumer Attention Deficit Syndrome (CADS) by Berg and Gornitzka [84], who argue that consumers tend to give their limited attention to consumption areas of a similar nature, while neglecting others. Based on this, Berg and Gornitzka [84] argue that consumer learning from information is limited, since consumers already suffer from information overload. These findings have important implications for policies aimed at reducing the climate impact of food consumption. Although it has been shown that information is an important factor affecting consumer behaviour, demand-side regulatory initiatives such as information provision will likely not be very effective alone. Consumer-oriented policies must also address the complexity of consumer choice and the broader context in which consumers find themselves.

The individualisation of responsibility as a form of environmental governance will only be effective if the governed subjects, in this case the consumers, respond to the ideas of green consumption and individualized responsibility [24]. The results of this study illustrate how people relate to environmentally sustainable consumption in ambiguous ways, and that the understanding of both the problem at hand and the consumers' responsibilities are negotiated and made sense of relative to a broader context. Both individual factors, such as value orientation, knowledge and scientific understanding, and competences and practices, as well as structural constraints such as product availability and the normative imperative imbued in discourses and governing techniques, are important factors influencing environmentally sustainable consumption of meat.

\subsection{Limitations and Future Research}

Together, these three studies are too limited to draw decisive conclusions, but illustrate that consumers are not very motivated to make food choices based on what is best for the climate, and point to some of the reasons why this is the case. As our studies are limited, both in scope and duration, further research, especially mixed-methods approaches, should be undertaken in order to assess and potentially verify our findings.

Future studies of in-store behaviour should attempt to include more stores and products, and increase the duration of the experiment. We designed our study as a typical promotion of vegetables, and compared the sales of vegetables in the weeks of the experiment with the sales the year before. Including data from non-treatment stores will be an improvement to the control treatments. In the current study, there is a mismatch between the goal of reducing meat consumption and having measured only the sales of vegetables. Including more product categories in the data collection and analysis will allow studies on the effect on, for example, meat and fish sales. Increasing the duration of the promotion period and including post-promotion sales will give results on long-term effects [85]. It would also be very interesting to test interventions targeting meat consumption directly, as negative labelling has often been found to be more effective than positive labelling [86-90]. In practice, grocery stores are seldom open to creating negative in-store promotions and are often very restrictive when it comes to sharing sales data with researchers.

\section{Conclusions}

Both at the global and local levels of governance, consumers are often allocated a large share of the responsibility for environmental sustainability. Consumers are perceived to be a part of the solution to complex problems such as climate change, and they are expected to be aware of their responsibility. In the context of food, one of the most important contributions to reducing climate change would be to transition towards a plant-based and low-meat diet. In this article, we find that Norwegian 
consumers are hesitant about making this change. This is because they have limited knowledge about the climate impact of meat consumption, but also because they are resistant to the idea that this is their responsibility as consumers. Providing information about the climate benefits of reduced meat consumption in an in-store experiment had some effect on vegetable sales, but the effect was equally strong when providing information about the associated health benefits.

Based on these findings, we argue that environmental policies aiming to transfer part of the responsibility for reducing greenhouse gas emissions to food consumers is being challenged by the fact that consumers are still not ready to make food choices based on what is best for the climate. Information or understanding is insufficient on its own to drive changes in behaviours or practices. This suggests that most of the existing measures to influence consumers will be unsuccessful and that future campaigns need to raise awareness by communicating scientific evidence of both the impact of climate change and how reduced meat consumption can help solve climate change. Nevertheless, regulating the supply side would likely be more effective in reducing the climate impacts of meat consumption.

Author Contributions: Methodology, Software, Validation, Resources, Investigation, Writing-Original Draft Preparation, Writing-Review \& Editing, Visualization, Supervision (M.H.A., S.E.S., A.S. and F.A.). Conceptualization, Data Curation, Formal Analysis, (M.H.A., S.E.S. and A.S.). Funding Acquisition (M.H.A. and A.S.). Project Administration (M.H.A).

Funding: This research was funded partly by GreeNudge and partly by the Norwegian Research Council, grant number 207731 and grant number 267858.

Acknowledgments: Several actors and organization have contributed to this study. We would first like to thank ICA/RIMI, the supermarket chain where we conducted our field experiments. We would also like to thank the Information Office for Fruit and Vegetables and the environmental NGO, Future in Our Hands, for permission to use their logos on the booklets, and especially the Information Office for sharing their vegetable recipes with us.

Conflicts of Interest: The authors declare no conflict of interest. The funders had no role in the design of the study; in the collection, analyses, or interpretation of data; in the writing of the manuscript, and in the decision to publish the results.

\section{Appendix A. Sample Characteristics}

Table A1. Population and sample by age and gender (percent).

\begin{tabular}{ccccccc}
\hline Population & Age & \multicolumn{10}{c}{} \\
\hline & $\mathbf{1 8 - 2 9}$ years & $\mathbf{3 0 -} \mathbf{- 3 9}$ years & $\mathbf{4 0 - 4 9}$ years & $\mathbf{5 0 - 5 9}$ years & $\mathbf{6 0 - 8 9}$ years & Total \\
\hline Men & 10.3 & 9.2 & 9.7 & 8.4 & 12.3 & 49.9 \\
Women & 9.9 & 8.8 & 9.2 & 8.1 & 14.1 & 50.1 \\
Total & 20.3 & 18.0 & 18.9 & 16.5 & 26.5 & 100 \\
\hline Sample & & & & & & \\
\hline Men & 9.1 & 6.9 & 8.8 & 10.1 & 15.5 & 50.3 \\
Women & 10.8 & 6.1 & 8.1 & 8.7 & 16.0 & 49.7 \\
Total & 19.9 & 12.9 & 16.9 & 18.7 & 31.5 & 100 \\
\hline
\end{tabular}

Table A2. Population and sample by education level (percent).

\begin{tabular}{|c|c|c|}
\hline Highest Level of Education Achieved & Population 16 Years and Older * & Sample 18 Years and Older \\
\hline Primary and lower secondary education & \multirow{2}{*}{29.8} & 7.0 \\
\hline Vocational education and training & & 25.5 \\
\hline Upper secondary education & 42.9 & 40.9 \\
\hline Higher education, up to four years in duration & 20.8 & 18.4 \\
\hline Higher education, more than four years in duration & 6.5 & 8.2 \\
\hline Total & 100 & 100 \\
\hline Number & $3,877,727$ & 1532 \\
\hline
\end{tabular}




\section{Appendix B. Operationalisation of Variables}

Table A3. Operationalisation of variables.

\begin{tabular}{|c|c|c|}
\hline Variable & Operationalisation & Mean (SD) \\
\hline \multicolumn{3}{|l|}{ Dependent variables } \\
\hline Meat-free meal & $\begin{array}{l}\text { Measured at ordinal level based on evaluations of the statement "It is a good idea for the environment to have a meat-free } \\
\text { day per week". The response alternatives consist of a five-point Likert scale from strongly disagree (1) to strongly agree } \\
\text { (5) in addition "don't know" and no response. Respondents who answered "don't know" are excluded from the analysis. }\end{array}$ & $3.40(1.41)$ \\
\hline Increase prices & $\begin{array}{l}\text { Measured at ordinal level based on evaluations of the statement "The prices on meat products should be increased for } \\
\text { environmental reasons". The response alternatives consist of a five-point Likert scale from strongly disagree (1) to } \\
\text { strongly agree (5) in addition "don't know" and no response. Respondents who answered "don't know" are excluded } \\
\text { from the analysis. }\end{array}$ & $2.20(1.22)$ \\
\hline \multicolumn{3}{|l|}{ Demographic variables } \\
\hline Gender & Measured at nominal level, $0=$ man, $1=$ woman. & $0.50(0.50)$ \\
\hline Age & Measured at ordinal level with five categories, $0=18-29,1=30-39,2=40-49,3=50-59,4=60+$. & $2.11(1.48)$ \\
\hline Education level & $\begin{array}{l}\text { Measured at nominal level based on the question "What is the highest level of education you have completed?" } \\
\text { The analysis employs a dummy variable for higher education = education at university college or university level (1). } \\
\text { Lower education (primary school, secondary school and upper secondary school) constitute the reference category (0). }\end{array}$ & $0.26(0.44)$ \\
\hline Income & $\begin{array}{l}\text { Measured at ordinal level based on the question "Approximately how large is your annual gross income (before taxes } \\
\text { and deductions)?" The response alternatives consist of six categories: } 0=\text { less than NOK } 200,000,1=\text { NOK } 200,000-\text { NOK } \\
299,999,2=\text { NOK } 300,000-\text { NOK } 399,999,3=\text { NOK } 400,000-\text { NOK } 599,999,4=\text { NOK } 600,000-\text { NOK } 799,999,5=\text { more than } \\
\text { NOK } 800,000 .\end{array}$ & $1.81(1.33)$ \\
\hline Income residual category & $\begin{array}{l}\text { Measured at nominal level as } 1=\text { do not want to provide this information, } 0=\text { NOK } 200,000-\text { NOK } 299,999,2=\text { NOK } \\
300,000-\text { NOK } 399,999,3=\text { NOK } 400,000-\text { NOK } 599,999,4=\text { NOK } 600,000-\text { NOK } 799,999,5=\text { more than NOK } 800,000 .\end{array}$ & $0.06(0.25)$ \\
\hline
\end{tabular}


Table A3. Cont.

\begin{tabular}{|c|c|c|}
\hline Variable & Operationalisation & Mean (SD) \\
\hline \multicolumn{3}{|l|}{ Value and attitudinal variables } \\
\hline Values & $\begin{array}{l}\text { Measured as an index }(\alpha=0.70) \text { combining respondents' replies to four statements: (1) A high level of taxes keeps public } \\
\text { services secure, (2) The problems facing developing countries matter to us all, (3) More of the tasks performed by the } \\
\text { public sector today should be performed by the private sector, }(4) \text { Government intrudes too much into people's lives. } \\
\text { The response alternatives consist of a five-point scale from strongly agree (1) to strongly disagree (5) in addition "don't } \\
\text { know" and no response. Respondents who answered "don't know" are excluded from the analysis. The scale used in the } \\
\text { analysis goes from most collectivistic (0) to most individualistic (4) values. }\end{array}$ & $2.42(0.74)$ \\
\hline Climate scepticism & $\begin{array}{l}\text { Measured as an index ( } \alpha=0.91) \text { combining respondents' replies to } 12 \text { statements about climate change: (1) I am certain } \\
\text { that climate change is happening, (2) Floods and heat waves are not increasing in volume, they are just being reported } \\
\text { more by the media, (3) Climate change is largely human-made, (4) Reports that human activities cause climate change } \\
\text { are exaggerated, (5) We know enough today to say that climate change is a problem, (6) Climate change is receiving too } \\
\text { much attention, (7) In general, I would say that climate change is being exaggerated in the news, (8) I am worried about } \\
\text { the consequences climate change can have for us humans, (9) It is too early to say whether climate change represents a } \\
\text { problem, (10) Climate change is just natural variations in the earth's temperature, (11) Climate change is given too much } \\
\text { attention, (12) The evidence for climate change is reliable. The response alternatives consist of a five-point Likert scale } \\
\text { from strongly agree (1) to strongly disagree (5) in addition "don't know" and no response. Respondents who answered } \\
\text { "don't know" are excluded from the analysis. The scale used in the analysis goes from trust in climate science (0) to } \\
\text { climate scepticism (4). }\end{array}$ & $1.00(0.85)$ \\
\hline \multicolumn{3}{|l|}{ Practice variables } \\
\hline Hard to reduce meat consumption & $\begin{array}{l}\text { Measured at ordinal level based on the statement "It is hard for me to reduce meat consumption". The response } \\
\text { alternatives consist of a five-point Likert scale from strongly disagree (0) to strongly agree (4) in addition "don't know" } \\
\text { and no response. }\end{array}$ & $1.89(1.28)$ \\
\hline Have reduced meat consumption & $\begin{array}{l}\text { Measured at nominal level based on the question "Have environmental problems caused you to reduce your meat } \\
\text { consumption?" The response alternatives consist of no (0) and yes (1) in addition to "don't know", "not relevant" } \\
\text { and no response. }\end{array}$ & $0.14(0.34)$ \\
\hline $\begin{array}{l}\text { Have reduced meat consumption } \\
\text { residual category }\end{array}$ & $\begin{array}{l}\text { Measured at nominal level based on the question "Have environmental problems caused you to reduce your meat } \\
\text { consumption?" The response alternatives consist of "no" (0) and "yes" (0) in addition to "don't know" (1), "not relevant" } \\
\text { (1) and no response. Respondents who answered "don't know" or "not relevant" constitutes the residual category. }\end{array}$ & $0.07(0.26)$ \\
\hline
\end{tabular}




\section{Appendix C. Overview of Focus Group Participants}

Table A4. Overview of focus group participants.

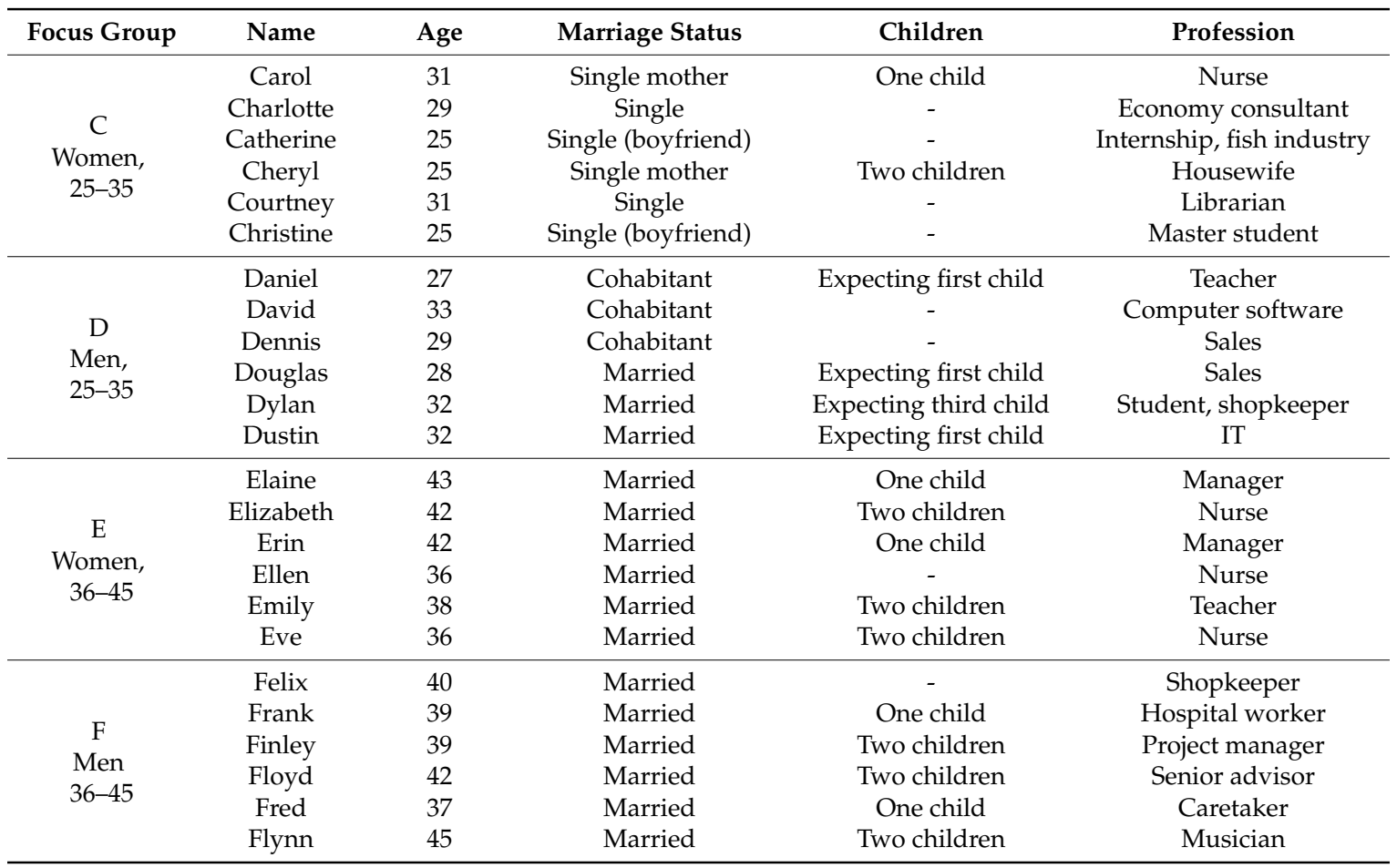

\section{Appendix D. Supplementary Illustrations}

The experiment used a stand displaying a poster at the top and booklets with 16 vegetable dinner recipes for at the bottom. Figure A1 shows how the booklet stands appeared in the stores.

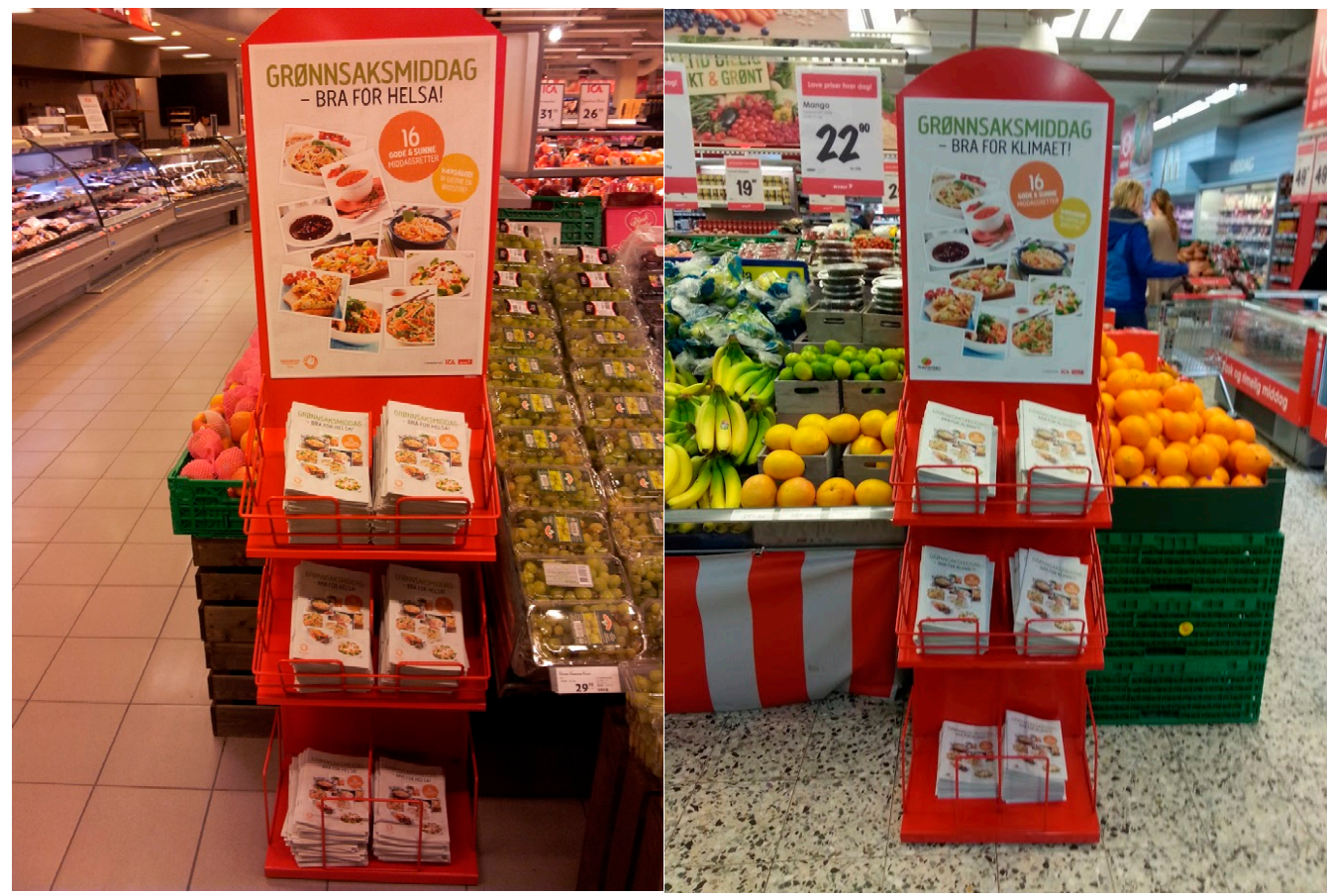

Figure A1. Placement of booklets in stores. 
The posters, front page of the booklets and the recipes inside the booklet were the same in the two treatments, except for the wording on the poster and front page. The message on the poster and front page of the booklets was framed as either a health or a climate message. The text on the poster and front page of the booklet was "Vegetable dinner—good for your health" or "Vegetable dinner—good for the climate". In the lower-left corner of the poster and front page, the health version had a "Five a day" logo from the Information Office for Fruit and Vegetables, while the climate version had the logo of the environmental organisation Future in Our Hands. Both organisations are well known in Norway.

A second difference between the two treatments was the text on the second page of the booklet. In the health version there was a short text written by the Information Office for Fruit and Vegetables describing why it is good for your health to eat vegetables. The climate version had a short text written by the environmental organisation explaining why eating vegetables is good for the climate. These texts were not visible unless you opened the booklet. Figure A2 shows the front page of the two recipe booklets.
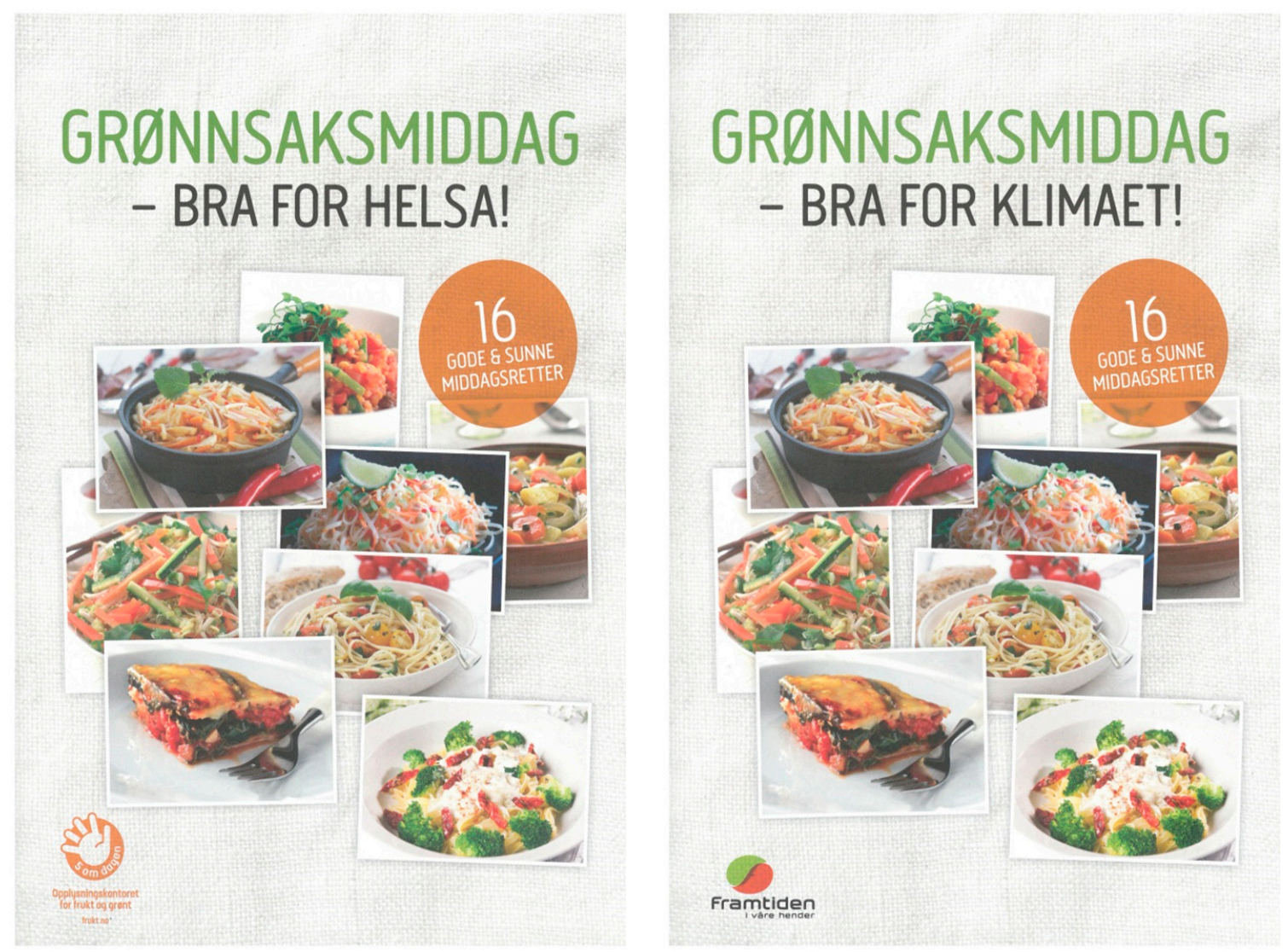

Figure A2. Front pages of recipe booklets. Health framing (left) and climate framing (right). 


\section{Appendix E. Figures Sales Data}

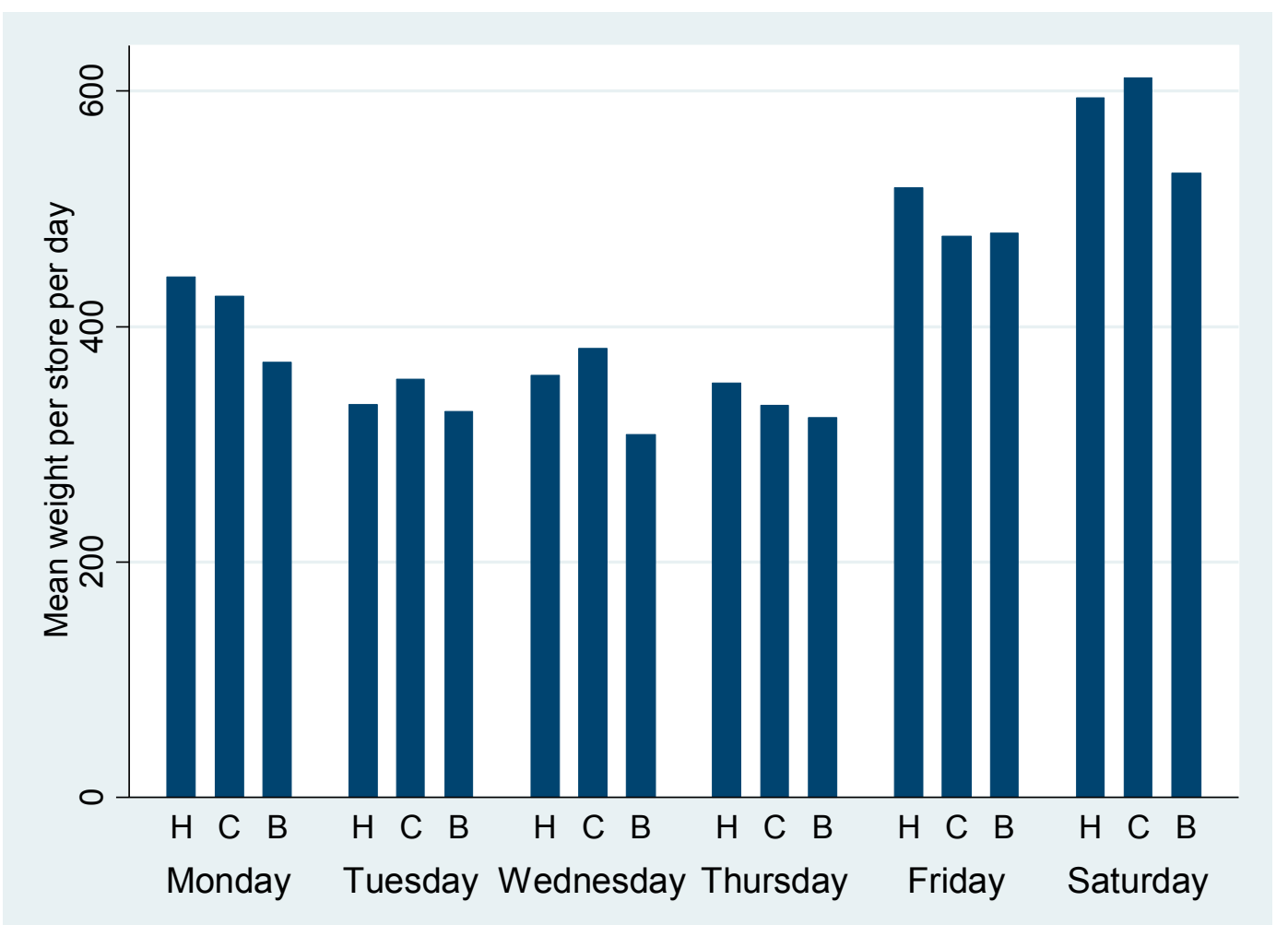

Figure A3. Sales in kilogram per store per day. Treatment and weekdays.

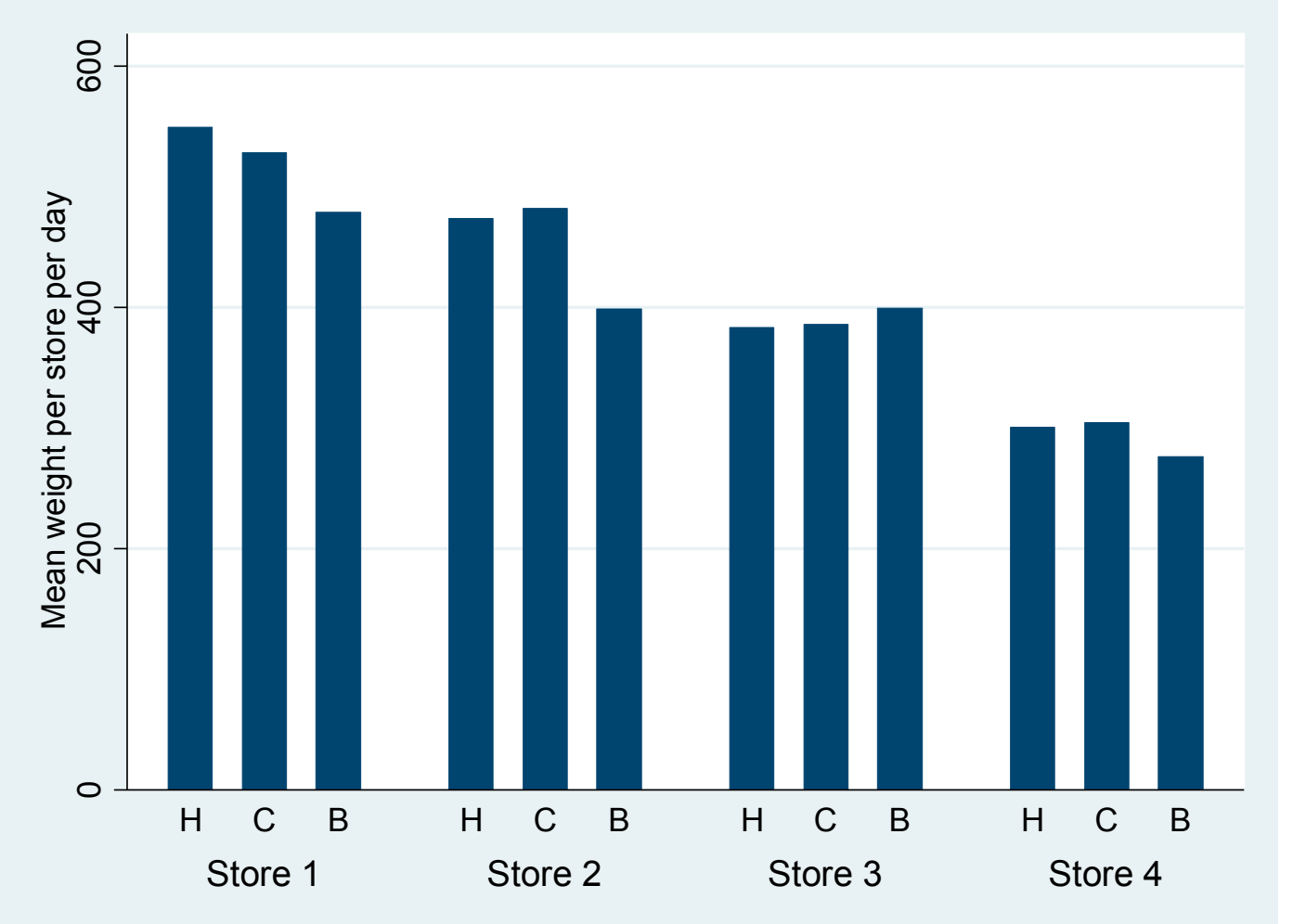

Figure A4. Sales in kilogram per store per day. Treatment and store number. 


\section{Appendix F. Sales Data}

Table A5. Sales dataset. Sales in kilograms per store per day with information on store number, weekday and treatments.

\begin{tabular}{|c|c|c|c|c|c|}
\hline Day & Store & Weekday & Health & Climate & $\mathrm{Kg}$ \\
\hline 1 & 1 & 1 & 0 & 0 & 516 \\
\hline 1 & 2 & 1 & 0 & 0 & 431 \\
\hline 1 & 3 & 1 & 0 & 0 & 353 \\
\hline 1 & 4 & 1 & 0 & 0 & 286 \\
\hline 2 & 1 & 2 & 0 & 0 & 375 \\
\hline 2 & 2 & 2 & 0 & 0 & 342 \\
\hline 2 & 3 & 2 & 0 & 0 & 312 \\
\hline 2 & 4 & 2 & 0 & 0 & 245 \\
\hline 3 & 1 & 3 & 0 & 0 & 450 \\
\hline 3 & 2 & 3 & 0 & 0 & 333 \\
\hline 3 & 3 & 3 & 0 & 0 & 299 \\
\hline 3 & 4 & 3 & 0 & 0 & 205 \\
\hline 4 & 1 & 4 & 0 & 0 & 434 \\
\hline 4 & 2 & 4 & 0 & 0 & 315 \\
\hline 4 & 3 & 4 & 0 & 0 & 343 \\
\hline 4 & 4 & 4 & 0 & 0 & 253 \\
\hline 5 & 1 & 5 & 0 & 0 & 534 \\
\hline 5 & 2 & 5 & 0 & 0 & 500 \\
\hline 5 & 3 & 5 & 0 & 0 & 596 \\
\hline 5 & 4 & 5 & 0 & 0 & 389 \\
\hline 6 & 1 & 6 & 0 & 0 & 671 \\
\hline 6 & 2 & 6 & 0 & 0 & 502 \\
\hline 6 & 3 & 6 & 0 & 0 & 653 \\
\hline 6 & 4 & 6 & 0 & 0 & 489 \\
\hline 7 & 1 & 1 & 0 & 0 & 494 \\
\hline 7 & 2 & 1 & 0 & 0 & 483 \\
\hline 7 & 3 & 1 & 0 & 0 & 331 \\
\hline 7 & 4 & 1 & 0 & 0 & 248 \\
\hline 8 & 1 & 2 & 0 & 0 & 386 \\
\hline 8 & 2 & 2 & 0 & 0 & 392 \\
\hline 8 & 3 & 2 & 0 & 0 & 362 \\
\hline 8 & 4 & 2 & 0 & 0 & 211 \\
\hline 9 & 1 & 3 & 0 & 0 & 358 \\
\hline 9 & 2 & 3 & 0 & 0 & 312 \\
\hline 9 & 3 & 3 & 0 & 0 & 300 \\
\hline 9 & 4 & 3 & 0 & 0 & 209 \\
\hline 10 & 1 & 4 & 0 & 0 & 397 \\
\hline 10 & 2 & 4 & 0 & 0 & 332 \\
\hline 10 & 3 & 4 & 0 & 0 & 297 \\
\hline 10 & 4 & 4 & 0 & 0 & 211 \\
\hline 11 & 1 & 5 & 0 & 0 & 505 \\
\hline 11 & 2 & 5 & 0 & 0 & 424 \\
\hline 11 & 3 & 5 & 0 & 0 & 540 \\
\hline 11 & 4 & 5 & 0 & 0 & 348 \\
\hline 12 & 1 & 6 & 0 & 0 & 663 \\
\hline 12 & 2 & 6 & 0 & 0 & 439 \\
\hline 12 & 3 & 6 & 0 & 0 & 524 \\
\hline 12 & 4 & 6 & 0 & 0 & 305 \\
\hline 13 & 1 & 1 & 0 & 0 & 446 \\
\hline 13 & 2 & 1 & 0 & 0 & 374 \\
\hline 13 & 3 & 1 & 0 & 0 & 276 \\
\hline 13 & 4 & 1 & 0 & 0 & 195 \\
\hline 14 & 1 & 1 & 1 & 0 & 555 \\
\hline
\end{tabular}


Table A5. Cont.

\begin{tabular}{|c|c|c|c|c|c|}
\hline Day & Store & Weekday & Health & Climate & $\mathrm{Kg}$ \\
\hline 14 & 2 & 1 & 0 & 1 & 503 \\
\hline 14 & 3 & 1 & 1 & 0 & 317 \\
\hline 14 & 4 & 1 & 0 & 1 & 248 \\
\hline 15 & 1 & 2 & 1 & 0 & 375 \\
\hline 15 & 2 & 2 & 0 & 1 & 418 \\
\hline 15 & 3 & 2 & 1 & 0 & 334 \\
\hline 15 & 4 & 2 & 0 & 1 & 256 \\
\hline 16 & 1 & 3 & 1 & 0 & 447 \\
\hline 16 & 2 & 3 & 0 & 1 & 464 \\
\hline 16 & 3 & 3 & 1 & 0 & 338 \\
\hline 16 & 4 & 3 & 0 & 1 & 236 \\
\hline 17 & 1 & 4 & 1 & 0 & 458 \\
\hline 17 & 2 & 4 & 0 & 1 & 381 \\
\hline 17 & 3 & 4 & 1 & 0 & 322 \\
\hline 17 & 4 & 4 & 0 & 1 & 252 \\
\hline 18 & 1 & 5 & 1 & 0 & 602 \\
\hline 18 & 2 & 5 & 0 & 1 & 475 \\
\hline 18 & 3 & 5 & 1 & 0 & 482 \\
\hline 18 & 4 & 5 & 0 & 1 & 350 \\
\hline 19 & 1 & 6 & 1 & 0 & 769 \\
\hline 19 & 2 & 6 & 0 & 1 & 520 \\
\hline 19 & 3 & 6 & 1 & 0 & 549 \\
\hline 19 & 4 & 6 & 0 & 1 & 475 \\
\hline 20 & 1 & 1 & 1 & 0 & 638 \\
\hline 20 & 2 & 1 & 0 & 1 & 610 \\
\hline 20 & 3 & 1 & 1 & 0 & 340 \\
\hline 20 & 4 & 1 & 0 & 1 & 312 \\
\hline 21 & 1 & 2 & 0 & 1 & 483 \\
\hline 21 & 2 & 2 & 1 & 0 & 466 \\
\hline 21 & 3 & 2 & 0 & 1 & 304 \\
\hline 21 & 4 & 2 & 1 & 0 & 220 \\
\hline 22 & 1 & 3 & 0 & 1 & 477 \\
\hline 22 & 2 & 3 & 1 & 0 & 374 \\
\hline 22 & 3 & 3 & 0 & 1 & 348 \\
\hline 22 & 4 & 3 & 1 & 0 & 276 \\
\hline 23 & 1 & 4 & 0 & 1 & 397 \\
\hline 23 & 2 & 4 & 1 & 0 & 363 \\
\hline 23 & 3 & 4 & 0 & 1 & 302 \\
\hline 23 & 4 & 4 & 1 & 0 & 266 \\
\hline 24 & 1 & 5 & 0 & 1 & 522 \\
\hline 24 & 2 & 5 & 1 & 0 & 570 \\
\hline 24 & 3 & 5 & 0 & 1 & 561 \\
\hline 24 & 4 & 5 & 1 & 0 & 417 \\
\hline 25 & 1 & 6 & 0 & 1 & 834 \\
\hline 25 & 2 & 6 & 1 & 0 & 579 \\
\hline 25 & 3 & 6 & 0 & 1 & 617 \\
\hline 25 & 4 & 6 & 1 & 0 & 479 \\
\hline 26 & 1 & 1 & 0 & 1 & 579 \\
\hline 26 & 2 & 1 & 1 & 0 & 546 \\
\hline 26 & 3 & 1 & 0 & 1 & 301 \\
\hline 26 & 4 & 1 & 1 & 0 & 256 \\
\hline 27 & 1 & 2 & 0 & 1 & 403 \\
\hline 27 & 2 & 2 & 1 & 0 & 420 \\
\hline 27 & 3 & 2 & 0 & 1 & 268 \\
\hline 27 & 4 & 2 & 1 & 0 & 187 \\
\hline
\end{tabular}




\section{References}

1. Aiking, H. Future protein supply. Trends Food Sci. Technol. 2011, 22, 112-120. [CrossRef]

2. Aiking, H. Protein production: Planet, profit, plus people? Am. J. Clin. Nutr. 2014, 100, 483S-489S. [CrossRef] [PubMed]

3. Bryngelsson, D.; Wirsenius, S.; Hedenus, F.; Sonesson, U. How can the EU climate targets be met? A combined analysis of technological and demand-side changes in food and agriculture. Food Policy 2016, 59, 152-164. [CrossRef]

4. Davis, J.; Sonesson, U.; Baumgartner, D.U.; Nemecek, T. Environmental impact of four meals with different protein sources: Case studies in Spain and Sweden. Food Res. Int. 2010, 43, 1874-1884. [CrossRef]

5. Garnett, T. Where are the best opportunities for reducing greenhouse gas emissions in the food system (including the food chain)? Food Policy 2011, 36, S23-S32. [CrossRef]

6. Hedenus, F.; Wirsenius, S.; Johansson, D.J.A. The importance of reduced meat and dairy consumption for meeting stringent climate change targets. Clim. Chang. 2014, 124, 79-91. [CrossRef]

7. Hoolohan, C.; Berners-Lee, M.; McKinstry-West, J.; Hewitt, C.N. Mitigating the greenhouse gas emissions embodied in food through realistic consumer choices. Energy Policy 2013, 63, 1065-1074. [CrossRef]

8. McMichael, A.J.; Powles, J.W.; Butler, C.D.; Uauy, R. Food, livestock production, energy, climate change, and health. Lancet 2007, 370, 1253-1263. [CrossRef]

9. Popp, A.; Lotze-Campen, H.; Bodirsky, B. Food consumption, diet shifts and associated non- $\mathrm{CO}_{2}$ greenhouse gases from agricultural production. Glob. Environ. Chang. 2010, 20, 451-462. [CrossRef]

10. Sabaté, J.; Soret, S. Sustainability of plant-based diets: Back to the future. Am. J. Clin. Nutr. 2014, 100, 476S-482S. [CrossRef] [PubMed]

11. Stehfest, E.; Bouwman, L.; van Vuuren, D.P.; den Elzen, M.G.J.; Eickhout, B.; Kabat, P. Climate benefits of changing diet. Clim. Chang. 2009, 95, 83-102. [CrossRef]

12. Schösler, H.; Boer, J.D.; Boersema, J.J. Can we cut out the meat of the dish? Constructing consumer-oriented pathways towards meat substitution. Appetite 2012, 58, 39-47. [CrossRef] [PubMed]

13. Westhoek, H.; Lesschen, J.P.; Rood, T.; Wagner, S.; De Marco, A.; Murphy-Bokern, D.; Leip, A.; van Grinsven, H.; Sutton, M.A.; Oenema, O. Food choices, health and environment: Effects of cutting Europe's meat and dairy intake. Glob. Environ. Chang. 2014, 26, 196-205. [CrossRef]

14. Allievi, F.; Vinnari, M.; Luukkanen, J. Meat consumption and production-Analysis of efficiency, sufficiency and consistency of global trends. J. Clean. Prod. 2015, 92, 142-151. [CrossRef]

15. Steinfeld, H.; Gerber, P.; Wassenaar, T.; Castel, V.; Rosales, M.; de Haan, C. Livestock's Long Shadow, Environmental Issues and Options; Food and Agricultire Organization of the United Nations: Rome, Italy, 2006.

16. Kearney, J. Food consumption trends and drivers. Philos. Trans. R. Soc. B Biol. Sci. 2010, 365, $2793-2807$. [CrossRef] [PubMed]

17. Animalia. Kjøttets Tilstand 2017. Status i norsk kjøtt- og eggproduksjon; Animalia: Oslo, Norway, 2017.

18. Vittersø, G.; Kjærnes, U.; Austgulen, M.H. Sustainable consumption in the Norwegian political economy of beef. In The Consumer in Society: A Tribute to Eivind Stø; Strandbakken, P., Gronow, J., Eds.; Abstrakt: Oslo, Norway, 2015; pp. 267-290. ISBN 978-82-7935-369-0.

19. Norwegian Ministry of Agriculture and Food. Klimautfordringene_Landbruket en del av Løsningen; Norwegian Ministry of Agriculture and Food: Oslo, Norway, 2009.

20. Austgulen, M.H. Environmentally Sustainable Meat Consumption: An Analysis of the Norwegian Public Debate. J. Consum. Policy 2014, 37, 45-66. [CrossRef]

21. Horne, S. Forbrukernes ansvar i miljø- og klimapolitikken; Ministry of Children and Equality: Oslo, Norway, 2014. Available online: https://www.regjeringen.no/no/aktuelt/forbrukernes-ansvar-i-miljo--og-klimapol/ id749342/ (accessed on 12 October 2014).

22. Boström, M.; Klintman, M. Can we rely on 'climate-friendly' consumption? J. Consum. Cult. 2017. [CrossRef]

23. Halkier, B. Consumption Challenged: Food in Medialised Everyday Lives; Ashgate: Burlington, VT, USA, 2010.

24. Soneryd, L.; Uggla, Y. Green governmentality and responsibilization: New forms of governance and responses to 'consumer responsibility'. Environ. Politics 2015, 24, 913-931. [CrossRef]

25. Wahlen, S.; Heiskanen, E.; Aalto, K. Endorsing Sustainable Food Consumption: Prospects from Public Catering. J. Consum. Policy 2012, 35, 7-21. [CrossRef] 
26. Thøgersen, J. How May Consumer Policy Empower Consumers for Sustainable Lifestyles? J. Consum. Policy 2005, 28, 143-177. [CrossRef]

27. Smismans, S. New Modes of Governance and the Participatory Myth. West Eur. Politics 2008, 31, 874-895. [CrossRef]

28. Gandenberger, C.; Garrelts, H.; Wehlau, D. Assessing the Effects of Certification Networks on Sustainable Production and Consumption: The Cases of FLO and FSC. J. Consum. Policy 2011, 34, 107-126. [CrossRef]

29. Rumpala, Y. "Sustainable consumption" as a new phase in a governmentalization of consumption. Theory Soc. 2011, 40, 669. [CrossRef]

30. Brom, F.W.A. Food, Consumer Concerns, and Trust: Food Ethics for a Globalizing Market. J. Agric. Environ. Ethics 2000, 12, 127-139. [CrossRef]

31. Micheletti, M.; Stolle, D.; Follesdal, A. (Eds.) Politics, Products, and Markets: Exploring Political Consumerism Past and Present; Transaction Publishers: New Brunswick, NJ, USA, 2004; 311p.

32. Harrison, R.; Newholm, T.; Shaw, D. (Eds.) The Etical Consumer; Sage: London, UK, 2005; 259p.

33. Kjærnes, U. Regulating Food Consumption. Studies of Change and Variation in Europe; University of Helsinki: Helsinki, Finland, 2008.

34. Miller, P.; Rose, N. Governing the Present. Administering Economic, Social and Personal Life; Polity: Cambridge, UK, 2008; 246p.

35. Pohjolainen, P.; Tapio, P.; Vinnari, M.; Jokinen, P.; Räsänen, P. Consumer consciousness on meat and the environment-Exploring differences. Appetite 2016, 101, 37-45. [CrossRef] [PubMed]

36. Macdiarmid, J.I.; Douglas, F.; Campell, J. Public awareness of the environmental impact of food and reluctance to eat less meat as part of a sustainable diet. Appetite 2016, 96, 487-793. [CrossRef] [PubMed]

37. Tobler, C.; Visschers, V.H.M.; Siegrist, M. Eating green. Consumers' willingness to adopt ecological food consumption behaviors. Appetite 2011, 57, 674-682. [CrossRef] [PubMed]

38. Truelove, H.B.; Parks, C. Perceptions of behaviors that cause and mitigate global warming and intentions to perform these behaviors. J. Environ. Psychol. 2012, 32, 246-259. [CrossRef]

39. Vanhonacker, F.; Van Loo, E.J.; Gellynck, X.; Verbeke, W. Flemish consumer attitudes towards more sustainable food choices. Appetite 2013, 62, 7-16. [CrossRef] [PubMed]

40. Bailey, R.; Froggatt, A.; Wellesley, L. Livestock-Climate Change's Forgotten Sector. Global Public Opinion on Meat and Dairy Consumption; Chatham House: London, UK, 2014.

41. Campbell-Arvai, V. Food-related environmental beliefs and behaviours among university undergraduates: A mixed-methods study. Int. J. Sustain. High. Educ. 2015, 16, 279-295. [CrossRef]

42. Clonan, A.; Wilson, P.; Swift, J.A.; Leibovici, D.G.; Holdsworth, M. Red and processed meat consumption and purchasing behaviours and attitudes: Impacts for human health, animal welfare and environmental sustainability. Public Health Nutr. 2015, 18, 2446-2456. [CrossRef] [PubMed]

43. Cole, M.; Miele, M.; Hines, P.; Zokaei, K.; Barry, E.; Beale, J. Animal foods and climate change: Shadowing eating practices. Int. J. Consum. Stud. 2009, 33, 162-167. [CrossRef]

44. de Boer, J.; Schösler, H.; Boersema, J.J. Climate change and meat eating: An inconvenient couple? J. Environ. Psychol. 2013, 33, 1-8. [CrossRef]

45. de Boer, J.; de Witt, A.; Aiking, H. Help the climate, change your diet: A cross-sectional study on how to involve consumers in a transition to a low-carbon society. Appetite 2016, 98, 19-27. [CrossRef] [PubMed]

46. Graça, J.; Calheiros, M.M.; Oliveira, A. Attached to meat? (Un)Willingness and intentions to adopt a more plant-based diet. Appetite 2015, 95, 113-125. [CrossRef] [PubMed]

47. Graça, J.; Oliveira, A.; Calheiros, M.M. Meat, beyond the plate. Data-driven hypotheses for understanding consumer willingness to adopt a more plant-based diet. Appetite 2015, 90, 80-90. [CrossRef] [PubMed]

48. Hartmann, C.; Siegrist, M. Consumer perception and behaviour regarding sustainable protein consumption: A systematic review. Trends Food Sci. Technol. 2017, 61, 11-25. [CrossRef]

49. Hoek, A.C.; Pearson, D.; James, S.W.; Lawrence, M.A.; Friel, S. Shrinking the food-print: A qualitative study into consumer perceptions, experiences and attitudes towards healthy and environmentally friendly food behaviours. Appetite 2017, 108, 117-131. [CrossRef] [PubMed]

50. Lea, E.; Worsley, A. Benefits and barriers to the consumption of a vegetarian diet in Australia. Public Health Nutr. 2003, 6, 505-511. [CrossRef] [PubMed]

51. Lea, E.; Worsley, A. Australian consumers' food-related environmental beliefs and behaviours. Appetite 2008, 50, 207-214. [CrossRef] [PubMed] 
52. Whitmarsh, L.; O'Neill, S. Green identity, green living? The role of pro-environmental self-identity in determining consistency across diverse pro-environmental behaviours. J. Environ. Psychol. 2010, 30, 305-314. [CrossRef]

53. de Boer, J.; Schösler, H.; Aiking, H. "Meatless days" or "less but better"? Exploring strategies to adapt Western meat consumption to health and sustainability challenges. Appetite 2014, 76, 120-128. [CrossRef] [PubMed]

54. De Groeve, B.; Bleys, B. Less Meat Initiatives at Ghent University: Assessing the Support among Students and How to Increase It. Sustainability 2017, 9, 1550. [CrossRef]

55. Verain, M.C.D.; Dagevos, H.; Antonides, G. Sustainable food consumption. Product choice or curtailment? Appetite 2015, 91, 375-384. [CrossRef] [PubMed]

56. Graça, J.; Calheiros, M.M.; Oliveira, A. Moral Disengagement in Harmful but Cherished Food Practices? An Exploration into the Case of Meat. J. Agric. Environ. Ethics 2014, 27, 749-765. [CrossRef]

57. de Boer, J.; Aiking, H. Pursuing a Low Meat Diet to Improve Both Health and Sustainability: How Can We Use the Frames that Shape Our Meals? Ecol. Econ. 2017, 142, 238-248. [CrossRef]

58. de Boer, J.; Aiking, H. On the merits of plant-based proteins for global food security: Marrying macro and micro perspectives. Ecol. Econ. 2011, 70, 1259-1265. [CrossRef]

59. Hoek, A.C.; Luning, P.A.; Weijzen, P.; Engels, W.; Kok, F.J.; de Graaf, C. Replacement of meat by meat substitutes. A survey on person- and product-related factors in consumer acceptance. Appetite 2011, 56, 662-673. [CrossRef] [PubMed]

60. Latvala, T.; Niva, M.; Mäkelä, J.; Pouta, E.; Heikkilä, J.; Kotro, J.; Forsman-Hugg, S. Diversifying meat consumption patterns: Consumers' self-reported past behaviour and intentions for change. Meat Sci. 2012, 92, 71-77. [CrossRef] [PubMed]

61. de Boer, J.; Hoogland, C.T.; Boersema, J.J. Towards more sustainable food choices: Value priorities and motivational orientations. Food Qual. Prefer. 2007, 18, 985-996. [CrossRef]

62. Kalof, L.; Dietz, T.; Stern, P.C.; Guagnano, G.A. Social Psychological and Structural Influences on Vegetarian Beliefs. Rural Sociol. 1999, 64, 500-511. [CrossRef]

63. Li, X.; Jensen, K.L.; Clark, C.D.; Lambert, D.M. Consumer willingness to pay for beef grown using climate friendly production practices. Food Policy 2016, 64, 93-106. [CrossRef]

64. Hunter, E.; Röös, E. Fear of climate change consequences and predictors of intentions to alter meat consumption. Food Policy 2016, 62, 151-160. [CrossRef]

65. Cordts, A.; Nitzko, S.; Spiller, A. Consumer Response to Negative Information on Meat Consumption in Germany. Int. Food Agribus. Manag. Rev. 2014, 17, 83-106.

66. Siegrist, M.; Visschers, V.H.M.; Hartmann, C. Factors influencing changes in sustainability perception of various food behaviors: Results of a longitudinal study. Food Qual. Prefer. 2015, 46, 33-39. [CrossRef]

67. Vainio, A.; Niva, M.; Jallinoja, P.; Latvala, T. From beef to beans: Eating motives and the replacement of animal proteins with plant proteins among Finnish consumers. Appetite 2016, 106, 92-100. [CrossRef] [PubMed]

68. GfK EU3C. Final Report-Consumer Market Study on the Functioning of the Meat Market for Consumers; European Union SANCO/2009/B1/010; European Union: Brussels, Belgium, 2012.

69. TNS Gallup. Teknisk Rapport. Holdning til Klimaendringer, Climate Crossroads; TNS Gallup: Oslo, Norway, 2011.

70. Skuland, S.E. Healthy Eating and Barriers Related to Social Class. The case of vegetable and fish consumption in Norway. Appetite 2015, 92, 217-226. [CrossRef] [PubMed]

71. Tjora, A.H. Kvalitative forskningsmetoder i praksis, 2nd ed.; Gyldendal Akademisk: Oslo, Norway, 2012; 246p.

72. Halkier, B. Fokusgrupper; Gyldendal Akademisk: Oslo, Norway, 2010.

73. Jenny, K. The methodology of Focus Groups: The importance of interaction between research participants. Sociol. Health Illn. 1994, 16, 103-121. [CrossRef]

74. Morgan, D.L. Focus Groups as Qualitative Research, 2nd ed.; Sage Publications: Thousand Oaks, CA, USA, 1997; 80p.

75. Opplysningskontoret for frukt og grønt. Totaloversikten. Frisk frukt, bær, grønnsaker og poteter 2010-2014. 2014. Available online: https:/ / www.frukt.no/globalassets/materiell/totaloversikten/totaloversikten-for2010-2014.pdf (accessed on 30 October 2017).

76. Corinna, H. Sales promotions and food consumption. Nutr. Rev. 2009, 67, 333-342. [CrossRef] 
77. Whitley, C.T.; Gunderson, R.; Charters, M. Public receptiveness to policies promoting plant-based diets: Framing effects and social psychological and structural influences. J. Environ. Policy Plan. 2018, 20, 45-63. [CrossRef]

78. Umberger, W.J.; Boxall, P.C.; Lacy, R.C. Role of credence and health information in determining US consumers' willingness-to-pay for grass-finished beef. Aust. J. Agric. Resour. Econ. 2009, 53, 603-623. [CrossRef]

79. Wibeck, V.; Linnér, B.O. Public understanding of uncertainty in climate science and policy. In Global Change Management: Knowledge Gaps, Blindspots and Unknowables; Ibisch, P., Gieger, L., Cybulla, F., Eds.; Nomos Verlag: Frankfurt, Germany, 2012; pp. 55-74. ISBN 978-3-8329-6714-7.

80. Kollmuss, A.; Agyeman, J. Mind the Gap: Why do people act environmentally and what are the barriers to pro-environmental behavior? Environ. Educ. Res. 2002, 8, 239-260. [CrossRef]

81. Vermeir, I.; Verbeke, W. Sustainable Food Consumption: Exploring the Consumer "Attitude-Behavioral Intention" Gap. J. Agric. Environ. Ethics 2006, 19, 169-194. [CrossRef]

82. Chawla, L. Life Paths Into Effective Environmental Action. J. Environ. Educ. 1999, 31, 15-26. [CrossRef]

83. Tvinnereim, E.; Fløttum, K.; Gjerstad, Ø.; Johannesson, M.P.; Nordø, Å.D. Citizens' preferences for tackling climate change. Quantitative and qualitative analyses of their freely formulated solutions. Glob. Environ. Chang. 2017, 46, 34-41. [CrossRef]

84. Berg, L.; Gornitzka, A. The consumer attention deficit syndrome: Consumer choices in complex markets. Acta Sociol. 2012, 55, 159-178. [CrossRef]

85. Cameron, A.J.; Charlton, E.; Ngan, W.W.; Sacks, G. A Systematic Review of the Effectiveness of Supermarket-Based Interventions Involving Product, Promotion, or Place on the Healthiness of Consumer Purchases. Curr. Nutr. Rep. 2016, 5, 129-138. [CrossRef]

86. Cawley, J.; Sweeney, M.J.; Sobal, J.; Just, D.R.; Kaiser, H.M.; Schulze, W.D.; Wethington, E.; Wansink, B. The impact of a supermarket nutrition rating system on purchases of nutritious and less nutritious foods. Public Health Nutr. 2015, 18, 8-14. [CrossRef] [PubMed]

87. Levy, D.E.; Riis, J.; Sonnenberg, L.M.; Barraclough, S.J.; Thorndike, A.N. Food Choices of Minority and Low-Income Employees. Am. J. Prev. Med. 2012, 43, 240-248. [CrossRef] [PubMed]

88. Scarborough, P.; Matthews, A.; Eyles, H.; Kaur, A.; Hodgkins, C.; Raats, M.M.; Rayner, M. Reds are more important than greens: How UK supermarket shoppers use the different information on a traffic light nutrition label in a choice experiment. Int. J. Behav. Nutr. Phys. Act. 2015, 12, 151. [CrossRef] [PubMed]

89. Thorndike, A.N.; Sonnenberg, L.; Riis, J.; Barraclough, S.; Levy, D.E. A 2-Phase Labeling and Choice Architecture Intervention to Improve Healthy Food and Beverage Choices. Am. J. Public Health 2012, 102, 527-533. [CrossRef] [PubMed]

90. Vanclay, J.K.; Shortiss, J.; Aulsebrook, S.; Gillespie, A.M.; Howell, B.C.; Johanni, R.; Maher, M.J.; Mitchell, K.M.; Stewart, M.D.; Yates, J. Customer Response to Carbon Labelling of Groceries. J. Consum. Policy 2011, 34, 153-160. [CrossRef] 